\title{
Increased Plasminogen Activator (Urokinase) in Tissue Culture After Fibrin Deposition
}

\author{
Maria B. Bernik with the technical assistance of Elizabeth P. Oller \\ From the Department of Medicine, Northwestern University Medical School \\ and Northwestern Memorial Hospital, Chicago, Illinois 60611
}

A B S T R A C T Lysis of fibrin in tissue culture has been shown to be due to plasminogen activator identified immunologically as urokinase. The present study examines fibrinolytic events in culture, particularly mechanisms leading to increased urokinase levels and accelerated fibrinolysis.

Deposition of fibrin on cells in culture was followed by a two- to six-fold increase in urokinase in the supernates and rapid disappearance of the fibrin. Investigation of factors that might be responsible for these events (including fibrin, fibrinogen, vasoactive stimuli, and the enzymes thrombin and plasmin) indicated that the enhanced urokinase yields were mediated through plasmin and thrombin.

Study of the possible modes of action of thrombin and plasmin indicated that these enzymes are capable of acting on the cells themselves as well as on cell-produced material. The effect on cells was manifested by mitotic activity or, occasionally, cell injury and death. Although these effects influenced urokinase levels, enhanced yields were explained best by the action of enzymes on cellproduced material. Studies with plasmin and thrombin, and also trypsin, indicated that proteolytic enzymes may act in various ways-affect the stability of urokinase, interfere with inhibition of urokinase by naturally occurring inhibitor(s), and induce urokinase activity from inactive material. Plasma and thrombin appeared to act primarily through the latter mechanisn.

Inactive material, which gave rise to urokinase upon exposure to proteolytic enzymes and which may represent urokinase precursor, was found in cultures of kidney, lung, spleen, and thyroid. Urokinase in such inactive state appears to be readily accessible to activation by enzymes, particularly plasmin and thrombin, thus

Abstract of preliminary results appeared in 1970 Clin. Res. 18: 398.

Received for publication 7 August 1972 and in recised form 27 November 1972. facilitating removal of fibrin and possibly also providing pathways to excessive fibrinolysis.

\section{INTRODUCTION}

Human tissues and cells in culture retain specific intrinsic functions and produce biological substances, including components of the fibrinolytic system (1-4). The ability of cultured renal cells to lyse fibrin clots is due to their production of plasminogen activator identified immunologically as urokinase $(\mathrm{UK})^{1}(1,2)$, and possessing physicochemical properties identical to those of UK (4). Studies of cultured tissues have demonstrated further that production of $\mathrm{UK}$ is not limited to the kidney but is a function of cells in various other organs (2). Investigation of cultures has shown that cells in many of these organs also produce inhibitor(s) of $\operatorname{UK}(2,3)$ similar to those described in serum (5) and extracted from tissues (6).

Studies of fibrinolytic events in living tissues in culture are facilitated by techniques that permit precise and direct observation of cells $(1,2,7)$ and assay of products which are released into chemically defined media (1-3). These techniques make possible examination of aspects of fibrinolysis not readily accessible in vivo. Such studies have suggested (8) that fibrin deposition on living cells sets in motion hitherto unrecognized mechanisms which lead to increased output of plasminogen activator and rapid disappearance of the fibrin, and, further, that these mechanisms are not initiated by the fibrin itself but may be mediated by local factors which develop in the course of fibrin formation or fibrinolysis. Cultures of human tissues are used in the present study to explore

'Abbreviations used in this paper: BME, Eagle's basal medium; FDP, fibrinogen digest products; HBSS, Hanks' balanced salt solution; PFF, plasminogen-free fibrin clots ; SBB, saline barbital buffer; SBTI, soybean trypsin inhibitor ; UK, urokinase. 
these mechanisms, attempt to determine the identity and mode of action of triggering factors, and examine their physiological significance in fibrin removal and possible implication in pathological fibrinolysis.

\section{METHODS}

\section{Culture models}

Culture models consisted of primary explants (9) of adult human kidney grown in Rose chambers as described previously $(1,2)$. The tissue was obtained by nephrectomies in seven patients and from cadaveric donors in two. Histology was normal in the two cadaver kidneys and in five surgical specimens where nephrectomies were performed for stag-horn calculi, noninvasive tumor, or unilateral renal artery disease. The remaining two specimens were obtained from pretransplant nephrectomies and showed advanced glomerulonephritis. All specimens were processed for culture within 1-2 $\mathrm{h}$ after they were obtained (one of the cadaver kidneys had been perfused in vitro for $24 \mathrm{~h}$ before receipt for culture). The tissues were cut into $1 \times 1 \mathrm{~mm}$ fragments under a dissecting microscope. Specimens from cortex and medulla were implanted separately into Rose chambers. Samples of tissue also were trypsinized (2) (Bacto-Difco 1:250, $0.25 \%$; Difco Laboratories, Detroit, Mich.) and the cells implanted in Rose chambers, tubes, and flat bottles.

Additional cultures were obtained from adult and fetal lung, fetal kidney, and adult spleen and thyroid. Lung, spleen, and thyroid tissues were trypsinized and the cells grown as primary cultures (9) in Rose chambers and bottles. Fetal kidneys were cultured both as primary explants and after trypsinization.

All cultures were fed standard medium (1-3) consisting of Eagle's basal medium (BME) and $10 \%$ fetal or newborn calf serum to which antibiotics were added ( $100 \mathrm{U}$ penicillin and $100 \mu \mathrm{g}$ streptomycin per $\mathrm{ml}$ ). Cultures were incubated at $37^{\circ} \mathrm{C}$. As outgrowth became established, the cultures were changed to chemically defined medium, $\mathrm{BME}$, containing $0.2 \%$ gelatin (1-3)

\section{Base-line studies}

After cultures were changed to $\mathrm{BME}$, cells were studied daily for 3-5 days as follows: viability and mitotic activity were observed by phase-contrast microscopy and microcinematography $(1,2)$. Supernatant medium was assayed daily for plasminogen activator and for inhibitor(s) content (2, $3)$. Cultures were refed at 1-2 day intervals to obtain several consecutive determinations of the spontaneous output of activator and inhibitor(s) after complete change of medium and to allow cells to adapt to the new, chemically defined environment.

\section{Experimental procedures}

After the base-line studies, cells were exposed to test materials as described below using primary explants of adult renal cortex grown in Rose chambers (four to six cultures from the same specimen for each of the test materials and an equal number of controls).

Fibrin clots, plasminogen-rich. Thin layers of fibrin were formed over the surface of cells, as described previously (2). The medium was removed from cultures and thrombin (Thrombin Topical, Parke-Davis \& Co., Detroit, Mich.; $0.1 \mathrm{ml}$ of $20 \mathrm{NIH} \mathrm{U} / \mathrm{ml}$ ) was injected into the chambers and allowed to flow over the cover slip on which the cells were growing. Excess thrombin $(0.02-0.04 \mathrm{ml})$ was drained off. $0.15 \mathrm{ml}$ of purified bovine plasminogen-rich fibrinogen ${ }^{2}$ $(0.7 \%, \mathrm{pH} 7.8$, ionic strength 0.15$)$ was placed over the cells and mixed with the thrombin by gently tilting the chamber. This formed a fibrin layer of even thickness which completely covered the cells and the glass cover slip on which they were growing. Cultures were then refed BME without disturbing the fibrin layer. Lysis of the clots by cells in culture was monitored by phase-contrast microscopy and time-lapse cinematography during incubation at $37^{\circ} \mathrm{C}$.

Fibrin clots, plasminogen-free ( $P F F$ clots). Thin layers of fibrin were formed over the surface of cells using bentonite-adsorbed fibrinogen ${ }^{2}$ (10) instead of plasminogenrich fibrinogen in the above procedure.

Fibrinogen, plasminogen-rich. Purified bovine fibrinogen was introduced into the cultures in a final concentration of 0.05 to $1.0 \mathrm{mg} / \mathrm{ml}$ of culture medium.

Fibrinogen, plasminogen-free. Bentonite-adsorbed fibrinogen (10) was substituted for plasminogen-rich fibrinogen in the above experiment.

Plasminogen-rich and plasminogen-free human fibrinogen (Mann Research Labs, Inc., New York) also were used in fibrin clot and fibrinogen experiments, yielding results essentially identical to those obtained with bovine preparations.

Thrombin. Two preparations were used, thrombin " $\mathrm{A}$ " and "B". Thrombin A, bovine (Parke-Davis), identical to that employed in fibrin clot experiments and containing $15 \mathrm{NIH} \mathrm{U} / \mathrm{mg}$, was introduced into the culture medium in a final concentration of $0.5-1.5 \mathrm{NIH} \mathrm{U} / \mathrm{ml}$ of culture medium. In higher concentrations this thrombin exhibited some plasminogen and traces of spontaneous fibrinolytic activity. Thrombin $\mathrm{B}$, bovine, plasminogen-free (Miles Laboratories, Inc., Kankakee, I11. ; Lot 11), was used in amounts of 0.2 to $2.5 \mathrm{mg} / \mathrm{ml}$ of culture medium. This thrombin showed traces of fibrinolytic activity but was free not only of plasminogen but also of clotting properties towards fibrinogen when assayed in concentrations up to $10 \mathrm{mg} / \mathrm{ml}$.

Human thrombin (Fibrindex, Ortho Diagnostic Div., Raritan, N. J.), containing approximately $10 \mathrm{NIH} \mathrm{U/mg,}$ was tested in preliminary studies and was found to contain plasminogen as well as fibrinolytic activity at concentrations as low as $0.5 \mathrm{NIH} \mathrm{U} / \mathrm{ml}$. This thrombin was therefore used primarily in experiments with cell-free systems, described below.

Plasmin. Glycerol-activated human plasmin ${ }^{3}$ (11) was introduced into the culture medium in amounts similar to those detected in cultures after exposure of cells to plasminogen-rich fibrin clots (0.1-0.2 CTA U/ml of medium).

Fibrin and fibrinogen digest products $(F D P)$. Various preparations were tested in preliminary studies to obtain FDP which were free of undesirable contaminants, particularly residual activity of proteolytic enzymes or excess inhibitor of the enzymes. Plasmin digest of human fibrinogen, lyophilized or frozen ${ }^{4}$ with or without added soybean trypsin inhibitor (SBTI), trypsin digest of human and bovine fibrinogen, and products obtained after separation on DEAE Sephadex columns ${ }^{5}$ (12) were tested in amounts

${ }^{2}$ Kindly supplied by Dr. T. Astrup, James F. Mitchell Foundation, Washington, D. C.

${ }^{3}$ Kindly supplied by Dr. J. T. Sgouris, Michigan Department of Health Laboratories, Lansing, Mich.

${ }^{4}$ Kindly supplied by Doctors R. Huseby (Eli Lilly \& Co., Indianapolis, Ind.) and G. H. Barlow (Abbott Laboratories, North Chicago, Ill.), respectively.

${ }^{5}$ Kindly supplied by Dr. J. Van Stone, Northwestern University Medical School, Chicago, Ill. 
of $0.01-1.0 \mathrm{mg} / \mathrm{ml}$. All preparations, however, showed persistent contamination with either traces of proteolytic enzymes or excess SBTI when assayed on fibrin plates. Limited culture studies were therefore done using FDP with least amounts of contaminants. These were obtained after $24 \mathrm{~h}$ of plasmin digestion ( 7.8 caseinolytic units of plasmin, $20 \mathrm{mg}$ human fibrinogen, in phosphate buffer, $\mathrm{pH}$ 7.6) and were introduced into the cultures in a final concentration of $0.01-0.02 \mathrm{mg} / \mathrm{ml}$ of culture medium.

Vasoactiz' drugs. Nicotinic acid or acetylcholine were introduced into the culture medium in amounts of $0.05-0.1$ $\mathrm{mg}$ and $10-20 \mu \mathrm{g} / \mathrm{ml}$ of medium, respectively (2).

After exposure to test materials, cells were monitored by phase-contrast microscopy and time-lapse cinematography $(1,2)$. Supernatant medium was assayed for plasminogen activator output at $3,5,8,16$, and $24 \mathrm{~h}$. Local plasminogen activator activity was examined in living cultures as well as cells that had been fixed (2). Test materials which induced changes in plasminogen activator levels in the culture models were studied further using cell-free test tube systems.

\section{Cell-free systems}

Tissue culture plasminogen activator was obtained from two sources: (a) purified activator isolated from supernates of human kidney cell cultures (4), with specific activity of $60,000 \mathrm{CTA} \mathrm{U} / \mathrm{mg}$ protein and containing no additives (albumin, gelatin) was provided by Abbott Laboratories, North Chicago, Ill. Activator of less purification $(5-6,000$ CTA $\mathrm{U} / \mathrm{mg}$ protein) was used in addition. Standards employed in the studies were prepared from stock solutions using saline barbital buffer ( $\mathrm{SBB})(\mathrm{pH} 7.75$, ionic strength $0.15)$, BME, or Hanks' balanced salt solution (HBSS) ; (b) freshly harvested cell-free supernates, exhibiting 4.0 8.0 CTA U/ml plasminogen activator, were obtained from kidneys cultured in chemically defined medium (BME) in tubes or bottles. Activators from both sources were found to be immunologically identical to urinary UK and were also inhibited by UK inhibitor(s) produced in culture (3). These plasminogen activators were designated tissue culture UK.

Inhibitory material was obtained from cultures of adult lung (3) and consisted of cell-free supernates collected from the cultures as well as retentates obtained after filtering the supernates through Amicon membranes (Amicon Corp., Lexington, Mass.) (3) and reconstituting the retained material in SBB, BME, or HBSS. Supernates and retentates inhibited 2.0 to $4.0 \mathrm{CTA} \mathrm{U} / \mathrm{ml}$ urinary or tissue culture $\mathrm{UK}$ but showed no effect towards the fibrinolytic activity of plasmin, trypsin, or thrombin. Inhibitory activity was destroyed by heating at $60^{\circ} \mathrm{C}$ for $30 \mathrm{~min}$ but was retained fully $(100 \%)$ at $37^{\circ} \mathrm{C}$ for $3 \mathrm{~h}$, and partly $(70-100 \%)$ after $24 \mathrm{~h}$ incubation at $37^{\circ} \mathrm{C}$.

Other culture-produced material used in cell-free systems consisted of supernates collected from kidney, spleen, thyroid, and fetal lung grown in chemically defined medium in tubes or bottles. These supernates were either free both of UK and inhibitory activity or exhibited low degree of one or the other activity.

Urokinase, inhibitor(s) of UK, and other material produced in tissue culture were studied before and after exposure to various test substances. UK (2.0-4.0 CTA U/ml in the final dilution), with or without added gelatin $(0.2 \%)$, or albumin (Human Fraction V, Miles Laboratories, 0.1$10 \mathrm{mg} / \mathrm{ml}$ ), was incubated with equal volumes of plasmin (0.02-0.8 CTA $\mathrm{U} / \mathrm{ml})$, bovine thrombin A $(1.0-75 \mathrm{NIH}$
$\mathrm{L} / \mathrm{ml})$, bovine thrombin $\mathrm{B}(0.1-5 \mathrm{mg} / \mathrm{ml})$, human thrombin $(0.5-20 \mathrm{NIH} \mathrm{U} / \mathrm{ml}$ ), or trypsin (Bacto-Difco 1:250, 0.02 $0.06 \mathrm{mg} / \mathrm{ml}$ ). Inhibitory material and other cell-free supernates from cultures were treated in a similar manner. Assays were performed after incubation periods ranging from $20 \mathrm{~min}$ to $24 \mathrm{~h}$ at $37^{\circ} \mathrm{C}$. UK, inhibitory and other cell-produced material, and test substances in equal volumes of SBB were assayed simultaneously and were used as controls. Additional controls were obtained by substituting the buffer with BME or HBSS. Test substances were used after being freshly prepared from stock as well as after heating at $56^{\circ}$ or $78^{\circ} \mathrm{C}$ for $30 \mathrm{~min}$, or after incubation at $37^{\circ} \mathrm{C}$ for up to $24 \mathrm{~h}$.

\section{Proteolytic enzymes}

Proteolytic enzymes used in the experiments were examined for the presence of contaminants as well as of properties that might interfere with assays, particularly assays of plasminogen activator.

Immunoprecipitation studies ${ }^{6}$ with antiserum to human serum albumin (Hyland Laboratories, Costa Mesa, Calif.) elicited a reaction band between albumin and human thrombin as well as among albumin and the two bovine thrombins, $\mathrm{A}$ and $\mathrm{B}$.

Plasminogen in the thrombins was estimated as described previously (13) by converting it to plasmin with UK and then assaying the plasmin activity on heated (14) and plasminogen-free (bovine fibrinogen, plasminogen-free, Miles Laboratories, Lot 12) fibrin plates. (All plates used in the study were prepared with 6.0 instead of $9.0 \mathrm{ml}$ fibrinogen to increase the sensitivity of the assays.) The human thrombin and thrombin A were found to contain up to $0.2-$ 0.3 CTA $\mathrm{U} / \mathrm{ml}$ plasminogen. This was destroyed partially by heating the thrombins at $56^{\circ} \mathrm{C}$ and completely at $78^{\circ} \mathrm{C}$.

Spontaneous fibrinolytic activity in the preparations of thrombin and trypsin was assayed on regular (15), heated, and plasminogen-free plates and was compared with that of plasmin standards. In the amounts used in the studies, the fibrinolytic activity of the thrombins was equivalent to $0-0.1$ CTA U/ml plasmin, and that of trypsin to $0.06-0.1$ CTA $\mathrm{U} / \mathrm{ml}$. Least activity was present in thrombin A which showed only traces at $40 \mathrm{NIH} \mathrm{U} / \mathrm{ml}$ and none at lesser concentrations. The fibrinolytic activity of the thrombins remained stable at $37^{\circ} \mathrm{C}$ for $24 \mathrm{~h}$ but was destroyed $(80-100 \%)$ by heating at $56^{\circ} \mathrm{C}$ for $30 \mathrm{~min}$. The ability of thrombin $A$ and human thrombin to clot fibrinogen was lost during these procedures.

The low degree of fibrinolytic activity of trypsin, plasmin, and the thrombin preparations used in the studies did not interfere with assays of plasminogen activator and was distinguished further from activator activity using specific antisera to UK.

\section{Assays of plasminogen activator}

The fibrin plate technique (15) using plasminogen-rich fibrin plates was employed for assays of plasminogen activator activity as described previously $(1,2)$. Degree of activity was expressed in CTA units per milliliter. Heated fibrin plates (14), plates prepared with plasminogen-free fibrinogen, and plates containing specific antisera to UK were employed to distinguish plasminogen activator from nonspecific activity. Such activity was detected only when proteolytic enzymes were used experimentally in the studies.

\footnotetext{
${ }^{6}$ Kindly performed by Dr. S. Silberman, Veterans Administration Hospital, Hines, Ill.
}

Increased Urokinase After Fibrin Deposition 


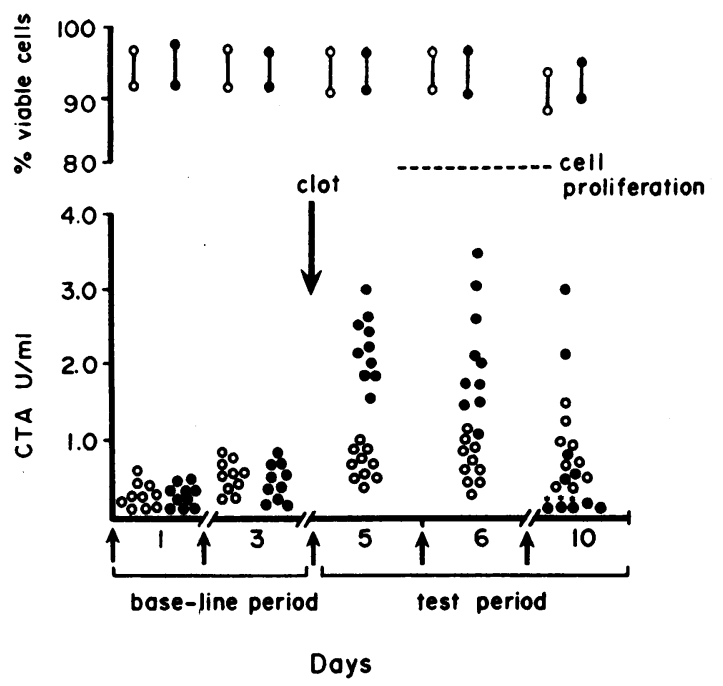

FIGURE 1 Increased plasminogen activator levels in cultures after exposure of cells to fibrin clots. Primary cultures of adult renal cortex, maintained on chemically defined serum-free medium, are studied for a base-line period and then exposed to thin, plasminogen-rich fibrin clots. Plasminogen activator content in the supernates is shown on the ordinate and the days of observations on the abscissa. Cultures receiving clots $(\bullet)$ exhibit a two- to sixfold increase in the $24 \mathrm{~h}$ output of plasminogen activator as compared with control cultures $(O)$ and to baseline outputs. Each circle represents individual values of cultures, 10 receiving clots and 10 controls. Arrows ( $\uparrow$ ) along the abscissa indicate refeedings of cultures and complete exchanges of the supernatant medium. Cell proliferation (---) is observed in cultures receiving clots. Inhibitor $(\mathrm{s})$ of plasminogen activator $\left(^{*}\right)$ are detected in the supernates of some cultures several days after the onset of cell proliferation. Fibrin plate assays.

Plasminogen activator was identified immunologically $(1,2)$ using fibrin plates which contained $\gamma$-globulin fraction from antisera against two urinary UK preparations (16). Antiserum to UK with specific activity of 125,000 CTA $\mathrm{U} / \mathrm{mg}$ protein, identical to that used previously (2), and antiserum to UK with specific activity of 35,000 CTA $\mathrm{U} / \mathrm{mg}$ protein ${ }^{7}$ were incorporated into fibrin plates in final concentrations of $1: 25,000$ and $1: 5,000$, respectively. In such concentrations the antisera showed similar degree of quenching towards urinary UK standards prepared from stock solutions with specific activity of $35,000 \mathrm{CTA} \mathrm{U} / \mathrm{mg}$ protein. ${ }^{8}$ Tissue culture UK standards, from purified or freshly harvested UK, were quenched to the same extent. $\gamma$-globulin from control sera showed no effect towards either urinary or tissue culture UK.

\section{Assays of inhibitor(s) of plasminogen activator}

Assays were performed as described previously (3). Supernates containing inhibitory activity were mixed in equal volumes with UK standards $(9.6$ to $0.6 \mathrm{CTA} \mathrm{U} / \mathrm{ml})$, incubated for $30 \mathrm{~min}$ at $37^{\circ} \mathrm{C}$ and assayed on fibrin plates.

\footnotetext{
${ }^{7}$ Kindly supplied by Doctors W. F. White and J. L. Lewis, respectively, Abbott Laboratories.

${ }^{8}$ Kindly supplied by Dr. G. H. Barlow, Abbott Laboratories.
}

Inhibitory activity was manifested by decrease or absence of lytic areas as compared with simultaneously assayed controls, and was recorded as units per milliliter of UK inhibited by the supernates. Control standards were assayed in SBB and in culture medium (BME) that had not been exposed to cells. Controls were also prepared using ultrafiltrates obtained by centrifuging the inhibitory culture supernates through Amicon membranes (3) which retain molecules larger than 50,000 molecular size but pass microsolutes and water freely. The filtrates showed no inhibitory effect while retentates exhibited $60-70 \%$ of the original inhibitory activity (3). Degree of inhibition was identical when tissue culture UK was substituted for urinary UK in the assays.

To distinguish antiurokinase from antiplasmin activity, supernates as well as filtrates and retentates were assayed using two substrates, fibrin and casein, as reported previously (3). No effect towards plasmin was detected in these assays, indicating that inhibitory activity, when present, was directed against UK. The fibrinolytic activity of trypsin and the thrombins also was not affected when. these enzymes were substituted for plasmin in the fibrin plate assays.

\section{RESULTS}

Growth, survival, and cell population of cultures were similar to those described previously $(1,2)$. Primary explants of adult kidneys in Rose chambers began to show outgrowth after 5-7 days of culture and exhibited discrete sheets of cells in 10-15 days. Base-line studies showed that over $90 \%$ of the cells remained viable after they were changed to chemically defined medium and yielded plasminogen activator in the supernates after each refeeding, in amounts of $0.6-1.0 \mathrm{CTA} \mathrm{U} / \mathrm{ml}$ per 24 $\mathrm{h}$ in cultures of cortex and 1.5-3.0 CTA U/ml per $24 \mathrm{~h}$ in cultures of medulla.

\section{Local plasminogen activator activity}

Study of cells using fibrin clot techniques confirmed previous observations (2) that living cells exhibit considerably greater plasminogen activator activity than do fixed preparations. The latter exhibited up to $2 \%$ active cells in the cortex and up to $5 \%$ in the medulla after 10-20 min incubation with the fibrin, whereas living cultures showed 5- to 10 -fold greater number of active cells and lysis of fibrin as early as $60 \mathrm{~s}$ after exposure to plasminogen-rich clots. Lytic areas then enlarged rapidly so that lysis was complete in $60-90 \mathrm{~min}$ by cells from the medulla and $2-3 \mathrm{~h}$ by cells from the cortex. Plasminogen-free fibrin was not lysed by any of the cultures, indicating the absence of proteases which use fibrin as a substrate.

\section{Plasminogen activator in the supernates after exposure to fibrin clots}

Experimental deposition of regular fibrin clots on living cells in culture resulted in a two- to sixfold increase in the $24 \mathrm{~h}$ yield of plasminogen activator in the supernates (Fig. 1). Study of cultures during the $24 \mathrm{~h}$ period 
after fibrin deposition showed complete lysis of the clots and increasing activator content in supernates at $3 \mathrm{~h}$, or earlier, then a continued rise that leveled off after 8-16 h. Cell proliferation was observed at this point and for several days thereafter (Fig. 1). This was accompanied by persistent high yields of activator with eventual decrease to or below control and pre-experimental levels coinciding with the appearance of inhibitor(s) in the supernates (Fig. 1).

Immunoassays with antisera to UK (Fig. 2) showed that plasminogen activator elicited in the supernates after fibrin clots is immunologically identical to UK and to activator present spontaneously in cultures. Minute portions of activity not quenched by the antisera were detected in supernates after clot lysis and were presumably due to plasmin derived from activation of clot plasminogen by activator in the cultures.

Results of studies performed to determine whether the enhanced UK yields were induced by the clot itself or were mediated through other factors are shown in Fig. 2.

Fibrin clots, plasminogen-free (PFF clots) which are not lysed in culture failed to induce increase in UK levels either at $24 \mathrm{~h}$ (Fig. 2) or during periodic sampling of supernates at $2-3-\mathrm{h}$ intervals. Thus the clot itself or fibrin network as such are not responsible for enhanced $\mathrm{UK}$ yields.

Vasoactive drugs. Challenge with acetylcholine or nicotinic acid confirmed previous observations (2) that vasoactive stimuli do not induce increase in $\mathrm{UK}$ levels in culture (Fig. 2).

Plasmin. In contrast to PFF clot and vasoactive drugs, plasmin induced a marked increase in UK yields in the supernates (Fig. 2), similar to that observed with regular clots when activation of plasminogen to plasmin was accomplished in the cultures. After exposure to plasmin, UK levels began to increase at 1-3 $\mathrm{h}$ and progressively thereafter leveling off after 8-16 h. Traces of plasmin activity were detected in supernates for periods up to $24 \mathrm{~h}$ and accounted for the minute portions of activity not quenched by the anti-UK sera.

Fibrinogen. Exposure of cells to plasminogen-free and plasminogen-rich fibrinogen (Fig. 2) showed that fibrinogen itself has no effect on UK levels. The modest rise in UK with plasminogen-rich fibrinogen appeared to be related to low-grade activation of plasminogen to plasmin as evidenced by transient appearance of traces of nonspecific activity in the supernates.

Fibrinogen digest products. Exposure of cells to FDP appeared to reflect primarily the presence of either residual plasmin or excess SBTI (Fig. 2). Thus, yields of UK were high when FDP contained trace amounts of plasmin, and low when SBTI was present.

Thrombin of the type used in the fibrin clot experiments (thrombin A) failed to increase UK yields (Fig.

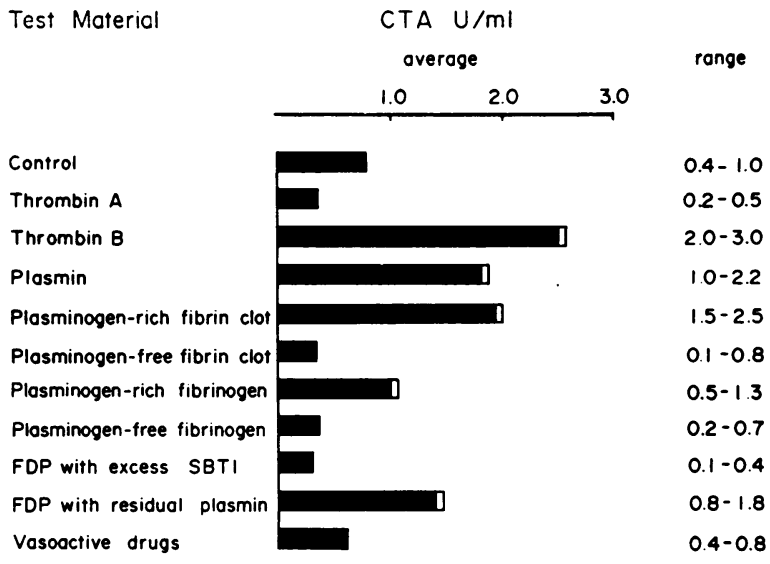

Figure 2 Plasminogen activator levels in cu!tures after exposure of cells to various test material including plasminogen-rich clots from Fig. 1. Cultures (10 for each of the test materials and an equal number of controls) of adult renal cortex are studied in the same way as those in Fig. 1. Bars represent average activity in the supernates 24 $h$ after challenge. Ranges are given in the column on the right. Solid bars illustrate quenching by specific antisera to urokinase and the open bars the fibrinolytic activity of the enzymes plasmin or thrombin in the test material. Increase in the $24-\mathrm{h}$ yields of urokinase is observed with plasminogen-rich clots, plasmin $(0.2 \mathrm{CTA} \mathrm{U} / \mathrm{ml})$, thrombin $\mathrm{B}(2.5 \mathrm{mg} / \mathrm{ml})$, and FDP $(0.02 \mathrm{mg} / \mathrm{ml})$ containing residual plasmin activity $(0.05-0.1 \mathrm{CTA} \mathrm{U} / \mathrm{ml})$. Assays are performed using regular, heated, and plasminogen-free plates, and plates containing antisera to urokinase.

2) when introduced into cultures in amounts similar to those employed in the clots $(0.5-1.5 \mathrm{NIH} \mathrm{U} / \mathrm{ml})$. Higher concentrations ( $30 \mathrm{NIH} \mathrm{U/ml} \mathrm{or} \mathrm{more)} \mathrm{induced}$ a modest increase in some cultures but also contained plasminogen which could be activated to plasmin in the cultures. However, enhanced UK yields were observed in the absence of plasminogen when thrombin $\mathrm{B}$ preparation was used in the studies (Fig. 2).

These observations indicate that the enhanced $U K$ yields after fibrin deposition are mediated through plasmin and, further, that thrombin may share some of the properties of plasmin. Possible models of action of these enzymes were examined in living cells and in cell-free systems.

\section{Living cells}

Cell proliferation observed after exposure of cultures to fibrin clots (Fig. 1) also occurred in the presence of plasmin or, to a lesser extent, thrombin. Bursts of mitotic activity were elicited by time-lapse cinematography after $6-8 \mathrm{~h}$ and cell proliferation was observed to continue for up to 72-96 h. Study of local plasminogen activator activity at $24-36 \mathrm{~h}$ showed $50-100 \%$ increase in the number of active cells. Cell proliferation thus may contribute to the sustained high levels of $\mathrm{UK}$ in the 


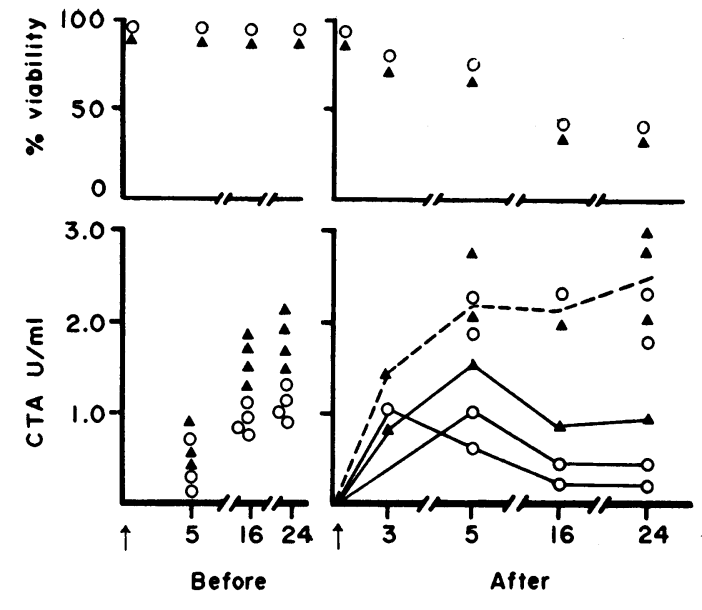

Hours

Figure 3 Urokinase yields before and after the onset of spontaneous cell death in cultures of adult renal cortex $(O)$ and medulla $(\boldsymbol{\Delta})$. Urokinase levels in the supernates of individual cultures are shown on the ordinate of the lower graphs and the time of observation on the abscissa. The upper graphs illustrate viability of cells. Arrows ( $\uparrow$ ) along the abscissa indicate refeeding of the cultures and complete exchange of the supernatant medium. Cell death is observed to result in high 24-h yields of urokinase in some cultures (-- -) while other cultures (-) exhibit transient peaks at 3 or $5 \mathrm{~h}$, followed by a drop in activity and low 24-h yields. Fibrin plate assays.

supernates but does not account for the enhanced yields which precede the onset of mitotic activity.

Cell injury and death. Examination of cultures by phase-contrast microscopy and time-lapse microcinematography during the studies illustrated in Figs. 1 and 2 revealed that cells remained viable and active throughout the experimental periods and. for several days thereafter. Cell death was minimal, affecting less than $5 \%$ of the total population. In the amounts used in the study, proteolytic enzymes generally were not toxic to the cultures. Some cells exhibited subtle "trypsin-like" effect, particularly with plasmin, consisting of slight rounding-up of cells with occasional detachment from the glass. However, there was no generalized sloughing or massive cell death, such as may be observed with larger concentrations of the enzymes.

Increased UK yields shown in Figs. 1 and 2 thus are not accounted for by release of active material from injured or dying cells. The effect of injury and death was nevertheless examined using cultures with high rate of mortality, spontaneous or plasmin-induced, encountered in fetal tissues which survived the experimental procedures poorly and observed also in cultures from two adult kidneys not included in the studies in Figs. 1 and 2. Cell death in such cultures was found to affect up to $80 \%$ of the population (Fig. 3) including most if not all fibrinolytically active cells. Assay of supernates after the on- set of cell death (Fig. 3) showed enhanced accumulation of UK in some cultures and transient high peaks followed by drop in UK and low $24 \mathrm{~h}$ yields in other cultures indicating that cell injury or death may mediate release of UK as well as of factor(s) leading to UK inactivation.

Spontaneous increase in UK levels was observed chiefly in cultures from renal medulla but also occurred in cultures from two specimens of renal cortex not included in the studies shown in Figs. 1 and 2. High UK yields, comparable to or higher than those obtained with test materials in Figs. 1 and 2, were found after the second or third refeeding of these cultures with BME and continued through the culture period of 4-6 wk. These cultures were characterized by rounding of the cells and occasional detachment from the glass, similar to a subtle "trypsin- (or plasmin-) like" effect. Exposure of cells to test material including fibrin clots, plasmin, or thrombin, failed to induce further increase in UK suggesting that mechanisms leading to enhanced UK had been activated "spontaneously" in these cultures, perhaps through enzyme(s) present in the tissue.

\section{Cell-free systems}

Results of studies using cell-free systems are shown in Figs. 4-10. These studies were designed to elucidate aspects of the fate of tissue culture UK, the role of proteolytic enzymes in these events and possible modes of

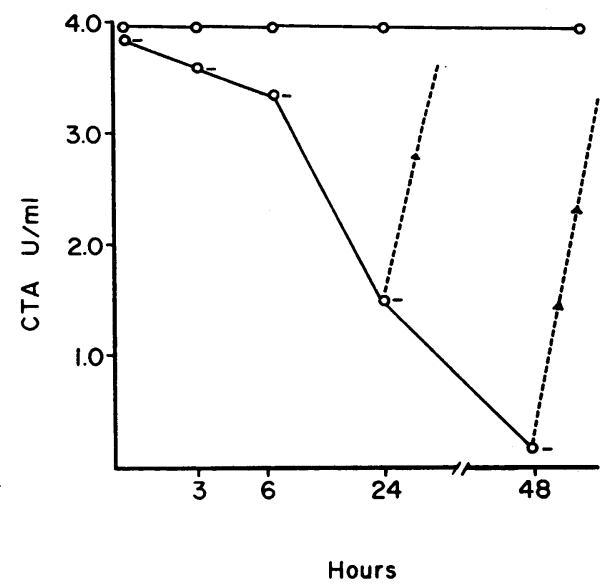

Figure 4 Stability of purified tissue culture urokinase during incubation in test tubes at $37^{\circ} \mathrm{C}$ in saline barbital buffer with $(\mathrm{O})$ and without $(\mathrm{O}-$ ) added gelatin $(0.2 \%)$. (Identical results are obtained when chemically defined culture medium [BME] or HBSS are substituted for the buffer in the assays.) Urokinase activity is shown on the ordinate and the time of incubation on the abscissa. In the absence of gelatin, urokinase is lost to the surface of the container (gelatin is present in all other studies [Figs. 1-3 and 5-10]). Dashed lines illustrate recovery of urokinase from the glass surface using buffer containing gelatin. Fibrin plate assays. 
action by which enzymes may increase the availability of UK. The following events were observed:

Adsorption of UK to glass surfaces (Fig. 4). In the absence of gelatin, UK was lost to the surface of the containers from where it was subsequently recovered by treatment with gelatin. When gelatin was present, activity of purified tissue culture UK remained essentially unchanged at $37^{\circ} \mathrm{C}$ for periods of $48 \mathrm{~h}$ to $2-4 \mathrm{wk}$ in saline barbital buffer, balanced salt solution or tissue culture medium, BME. Results identical to those shown in Fig. 4 were obtained when albumin was substituted for gelatin in the assays.

Thrombin and plasmin had no apparent effect on UK itself or its adsorption to surfaces. Activity of purified tissue culture UK and loss of this activity to surfaces shown in Fig. 4 were not modified during $24 \mathrm{~h}$ incubation with thrombin A $(0.2-2.0 \mathrm{NIH} \mathrm{U} / \mathrm{ml})$, thrombin $\mathrm{B}$ $(0.1-5.0 \mathrm{mg} / \mathrm{ml})$, or plasmin $(0.02-0.2 \mathrm{CTA} \mathrm{U} / \mathrm{ml})$.

Spontaneous degradation of $U K$. This was observed in UK of low purification (5-6000 CTA U/mg protein) as well as in UK harvested directly from cultures. Loss of activity in these preparations generally was modest, $20-30 \%$ or less, during $24 \mathrm{~h}$ incubation at $37^{\circ} \mathrm{C}$. Marked decrease in activity, similar to or greater than that shown in Fig. $5 b$ was observed chiefly in supernates of cultures after cell sloughing and death.

Spontaneous inactivation was reproduced in the test tube using purified tissue culture UK and trace amounts of trypsin (Fig. 5a) which also accelerated spontaneous loss of activity (Fig. $5 b$ ). Unlike the loss of UK to

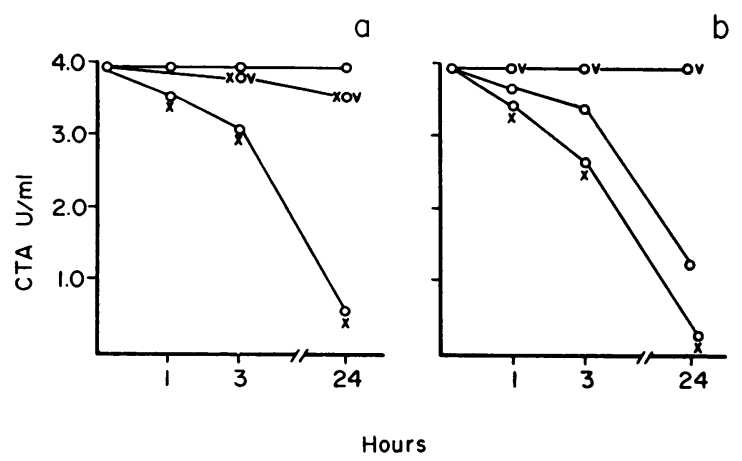

Figure 5 Trypsin-induced and spontaneous inactivation of urokinase during incubation at $37^{\circ} \mathrm{C}$. Urokinase activity is shown on the ordinate and the time of incubation on the abscissa. Studies are performed in cell-free test tube systems as follows: in graph $a$ purified tissue culture urokinase (O) is incubated with trace amounts $(0.03 \mathrm{mg} / \mathrm{ml})$ of tryp$\sin (\mathrm{X})$ in the presence and absence of albumin $(\mathrm{V})(0.5$ $\mathrm{mg} / \mathrm{ml}$ ). In graph $b$ urokinase harvested directly from cultures $(O)$ and showing spontaneous inactivation is treated with albumin (V) or trypsin ( $X)$. Trypsin causes loss of activity in purified preparations and accelerates that occurring spontaneously in culture harvests. Albumin prevents the spontaneous (graph $b$ ) as well as the trypsin-induced (graph a) inactivation. Fibrin plate assays.

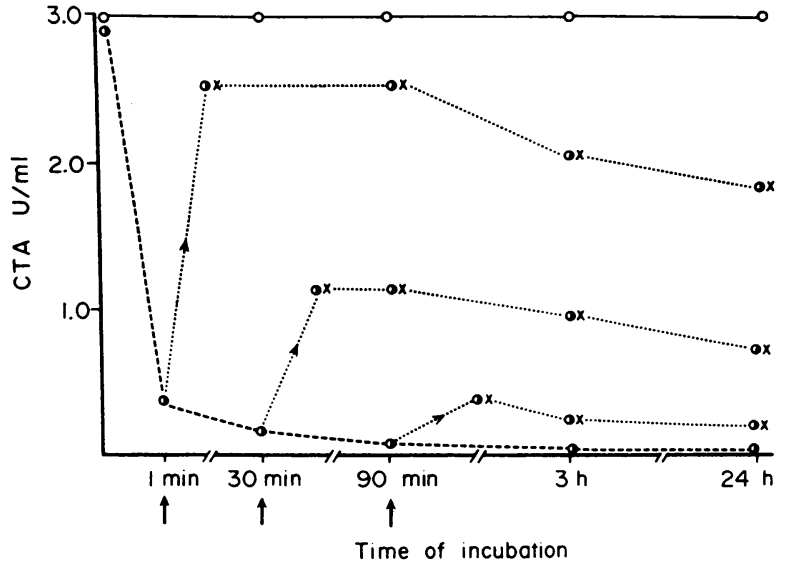

FIGURE 6 Effect of trypsin on urokinase-inhibitor reaction. The ordinate shows urokinase activity in CTA $\mathrm{U} / \mathrm{ml}$ and the abscissa the time of incubation at $37^{\circ} \mathrm{C}$. Studies are performed in cell-free, test tube system as follows: purified tissue culture urokinase $(\mathrm{O}-\mathrm{O})$ is allowed to react with inhibitor (s) obtained from lung cultures ( -0$)$. Inhibitory effect is manifested by immediate drop of urokinase activity followed by a further gradual decrease in activity. Trace amounts of trypsin $(0.03 \mathrm{mg} / \mathrm{ml})$ are added to portions of the urokinase-inhibitor mixture after 1,30 , or 90 $\min (\uparrow)$. Recovery of urokinase in trypsin-treated $(X)$ portions, shown by the dotted lines, is estimated using regular and heated plates and plates containing specific antisera to urokinase.

surfaces shown in Fig. 4, inactivation was not prevented by gelatin and activity was not recovered from the glass surfaces. However, both the spontaneous and trypsin-induced inactivation were prevented when albumin was introduced in the incubating mixtures (Fig. 5) in amounts of $0.5 \mathrm{mg}$, or more, per milliliter of medium. The activity of trypsin itself in fibrin plate assays was not affected by albumin in amounts up to $10 \mathrm{mg} / \mathrm{ml}$.

Ability to prevent inactivation of UK ("stabilizing" property), similar to that of albumin in Fig. 5, was elicited in thrombin preparations-thrombin A (2.0 or more $\mathrm{NIH} \mathrm{U} / \mathrm{ml}), \mathrm{B}(0.1$ or more $\mathrm{mg} / \mathrm{ml})$, or human (2.0 or more $\mathrm{NIH} \mathrm{U/ml)} \mathrm{-} \mathrm{and} \mathrm{was} \mathrm{retained} \mathrm{after} \mathrm{the}$ enzymes or albumin were heated at $56^{\circ}$ or $78^{\circ} \mathrm{C}$ for 30 min. or were incubated at $37^{\circ} \mathrm{C}$ for $24 \mathrm{~h}$. "Stabilizing" ability of plasmin $(0.2$ or more CTA U/ml) was weaker than that of albumin and the thrombins and was manifested primarily in delaying UK inactivation, spontaneous or trypsin-induced, for up to $3 \mathrm{~h}$.

Inhibition of $U K$ by inhibitor (s) produced in tissucs. In contrast to the inactivation shown in Fig. 5, inhibitory reaction was immediate (Fig. 6), was not prevented by albumin, thrombin, or plasmin, and was not accelerated by trypsin. In fact, when UK-inhibitor mixtures were treated with trypsin during the first $30 \mathrm{~min}$ of the in hibitory reaction, UK could be recovered (Fig. 6) both when purified or freshly harvested UK were used in the

Increased Urokinase After Fibrin Deposition 829 

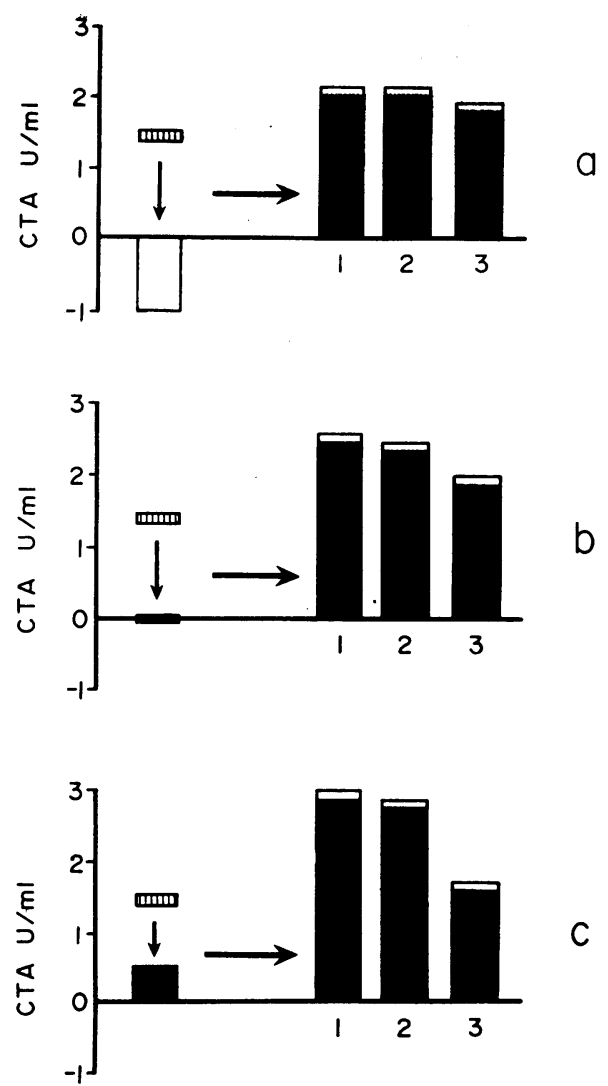

FIGURE 7 Urokinase activity induced by plasmin, thrombin, or trypsin in cell-free supernates of cultures. Studies are performed in test tubes as follows: trace amounts (shaded bars) of the enzymes $(0.2 \mathrm{CTA} \mathrm{U} / \mathrm{ml}$ plasmin, 2.5 $\mathrm{mg} / \mathrm{ml}$ thrombin $\mathrm{B}$, or $0.03 \mathrm{mg} / \mathrm{ml}$ trypsin) are added $(\downarrow)$ to cell-free supernates harvested from fetal $(a)$ or adult $\left(b\right.$ and $c$ ) kidney cultures. After $20 \mathrm{~min}$ incubation at $37^{\circ} \mathrm{C}$ $(\rightarrow)$ supernates are assayed on regular and heated fibrin plates and on plates containing specific antisera to urokinase. Before treatment with the enzymes, supernate from fetal kidney (a) exhibits inhibitor of urokinase, illustrated by the negative value on the lower part of the ordinate. One of the adult kidneys (c) (obtained at nephrectomy) contains trace amounts of urokinase shown on the upper part of the ordinate, while the other kidney $(b)$ (obtained from cadaveric donor and cultured after $24 \mathrm{~h}$ in vito perfusion) exhibits neither urokinase nor inhibitor. After incubation $(\rightarrow)$ with plasmin (1), thrombin (2) or trypsin (3), urokinase is present in all supernates in amounts up to 3.0 CTA $\mathrm{U} / \mathrm{ml}$. Closed bars represent quenching by specific antisera to urokinase and open bars, the nonspecific activity of the enzymes plasmin, thrombin, or trypsin.

experiments. Plasmin $(0.1-0.2 \mathrm{CTA} \mathrm{U} / \mathrm{ml})$ or thrombin $(B, 0.25-2.5 \mathrm{mg} / \mathrm{ml})$ failed to induce recovery of either UK.

Presence of inactive form $(s)$ of $U K$ gave rise to $U K$ activity upon exposure to proteolytic enzymes as illustrated in Fig. 7. Supernates harvested from cultures of fetal (Fig. 7a) or adult (Fig. $7 b$ and $c$ ) kidneys were studied before and after treatment with trace amounts of

trypsin, plasmin, or thrombin. Before incubation with the enzymes, these supernates showed little or no UK or exhibited only inhibitor(s) of UK. However, after 20 min incubation with thrombin, plasmin, or trypsin, UK was present in all supernates in amounts up to $3.0 \mathrm{CTA}$ $\mathrm{U} / \mathrm{ml}$. Albumin had no effect, although it increased trypsin-induced UK yields by $20-40 \%$, presumably by preventing degradation of $\mathrm{UK}$ by the trypsin. In assays with specific antisera and inhibitor(s), UK formed through the action of plasmin, thrombin, or trypsin was quenched and inhibited to the same extent as freshly harvested or purified UK preparations.

Results similar to those shown in Fig. 7 were obtained from two additional kidneys, one spleen, two thyroid and five fetal lung cultures. The inactive material in culture supernates which gave rise to UK upon treatment with proteolytic enzymes remained stable for $24 \mathrm{~h}$ at room temperature or for up to 6 months at $-20^{\circ} \mathrm{C}$, but was destroyed by repeated freezing and thawing, 24 $\mathrm{h}$ at $37^{\circ} \mathrm{C}$ or $30 \mathrm{~min}$ at $56^{\circ} \mathrm{C}$. The material was retained by Amicon membranes ( $\mathrm{CF} \mathrm{50)} \mathrm{(3),} \mathrm{indicating} \mathrm{that} \mathrm{its}$ molecular size was 50,000 or greater.

The ability of plasmin and thrombin to induce UK in inactive supernates was examined in relation to other properties of the enzymes as shown in Fig. 8 and further in Figs. 9 and 10. Plasmin retained the capacity to bring about UK activity after its fibrinolytic effect was lost by prolonged incubation or heating. 'Similar results were observed with thrombin-UK activity was induced with thrombin preparations which failed to clot fibrinogen (thrombin B) as well as those in which clotting property had been destroyed by heat (thrombin A and human thrombin). Study of the respective UK-inducing abilities of plasmin and the various thrombin preparations showed that plasmin brought about considerable UK activity when used in exceedingly small amounts, either freshly prepared or heat-treated (Fig. 9). Throm-

a

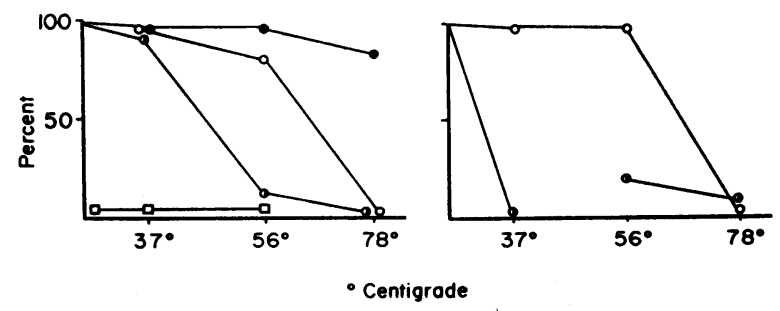

FIGURE 8 Stability of the various properties of thrombin $\mathrm{B}$ (graph $a$ ) and plasmin (graph $b$ ) at $37^{\circ}, 56^{\circ}$, and $78^{\circ} \mathrm{C}$. Fibrinolytic activity $(\circlearrowleft)$, clotting property $(\square)$, ability to prevent degradation of urokinase $(\bullet)$ or to induce urokinase in inactive supernates $(\mathrm{O})$ are assayed after incubating the enzymes $(0.2 \mathrm{CTA} \mathrm{U} / \mathrm{ml}$ plasmin, $2.5 \mathrm{mg} / \mathrm{ml}$ thrombin $\mathrm{B}$ ) at $37^{\circ} \mathrm{C}$ for $24 \mathrm{~h}$, or at $56^{\circ}$ or $78^{\circ}$ for $30 \mathrm{~min}$. Results are expressed as percent of the original activity. 
bin $\mathrm{B}$ and the human thrombin preparations also induced UK activity readily (Fig. 10), whereas thrombin A showed but weak effect and only after it had been heated (Fig. 10). Fresh preparations of this thrombin were found to contain an activity which interfered with or blocked formation of UK from inactive material. Thus, UK induction by plasmin, trypsin, thrombin B, and the human thrombin, shown in Figs. 7, 9, and 10, was abolished almost completely (up to $80 \%$ ) when freshly prepared thrombin A was present in the reacting mixtures in amounts of $10-20 \mathrm{NIH} \mathrm{U} / \mathrm{ml}$. Thrombin A did not inhibit preformed UK and also did not affect the fibrinolytic activity of plasmin, trypsin, and the other two thrombin preparations indicating that factor(s) "blocking" UK formation are distinct from fibrinolytic inhibitors such as antiurokinase and antiplasmin (3).

\section{DISCUSSION}

Concepts relating present findings to previously described aspects of fibrinolysis are delineated in Fig. 11 and interpreted as follows.

When fibrin clots are formed or fibrin is deposited in blood vessels or tissues, clot plasminogen is activated to plasmin by plasminogen activator (17) which originates from cells of organs and tissues $(1,2)$. Cells in many tissue also produce inhibitor(s) of plasminogen activator (3). Other inhibitor (s) formed in tissues (3) act on plasmin $(18,19)$ which ultimately is responsible for the lysis of the clots $(17,20)$. The present study indicates the occurrence of further local events relevant to fibrinolysis as well as to tissue repair processes that fol-

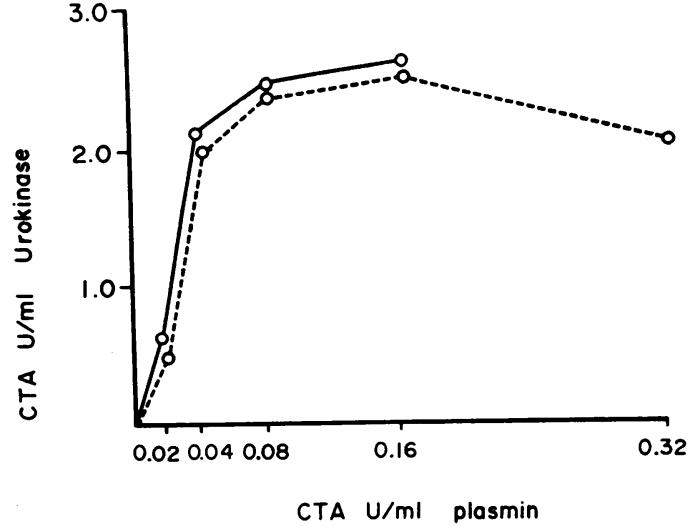

FIGURE 9 Plasmin-induced urokinase activity in cell-free supernates of cultures. Supernates harvested from kidney cultures identical to those of Fig. $7 b$ and containing no urokinase activity are mixed with equal volumes of progressively increasing concentrations of plasmin, freshly prepared (-) or heat-treated at $56^{\circ}$ for $30 \mathrm{~min}(-.-)$. The amount of plasmin in the mixtures is shown on the abscissa and urokinase elicited after $30 \mathrm{~min}$ incubation at $37^{\circ} \mathrm{C}$ on the ordinate. Assays are performed on regular and heated fibrin plates and on plates containing antisera to urokinase.

low fibrin deposition. In events pertaining to fibrinolysis. mechanisms are set in motion which increase the availability of the plasminogen activator UK and thus hasten the removal of fibrin. These mechanisms are not triggered by the clot itself or fibrin network as such, but are mediated through enzymes formed in the process of fibrinolysis and perhaps also in that of clotting, namely plasmin and thrombin.

a
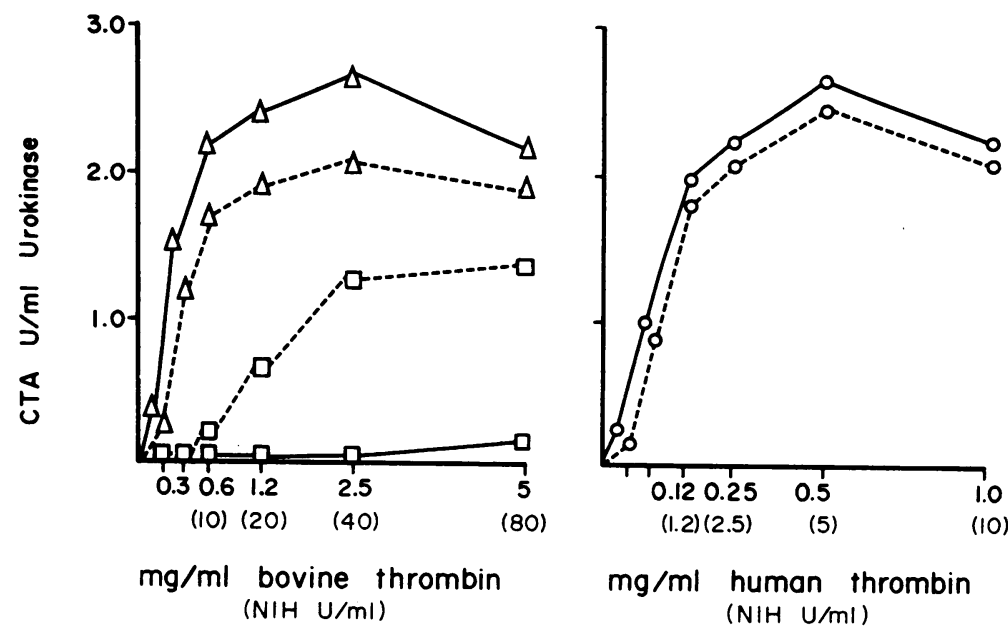

$\mathrm{mg} / \mathrm{ml}$ human thrombin ( $\mathrm{NIH} \mathrm{U/mI)}$

FIGURE 10 Thrombin-induced urokinase activity in cell-free supernates of cultures. Studies are performed as in Fig. 9 by substituting plasmin with bovine thrombin $A(\square)$ or $B(\triangle)$, or human thrombin $(\mathrm{O})$, freshly prepared $(-)$ or heat-treated at $56^{\circ} \mathrm{C}$ for $30 \mathrm{~min}(--)^{\circ}$. Thrombin $\mathrm{B}$ and human thrombin induce urokinase activity readily while thrombin $\mathrm{A}$ shows little or no effect until it has been heated. 


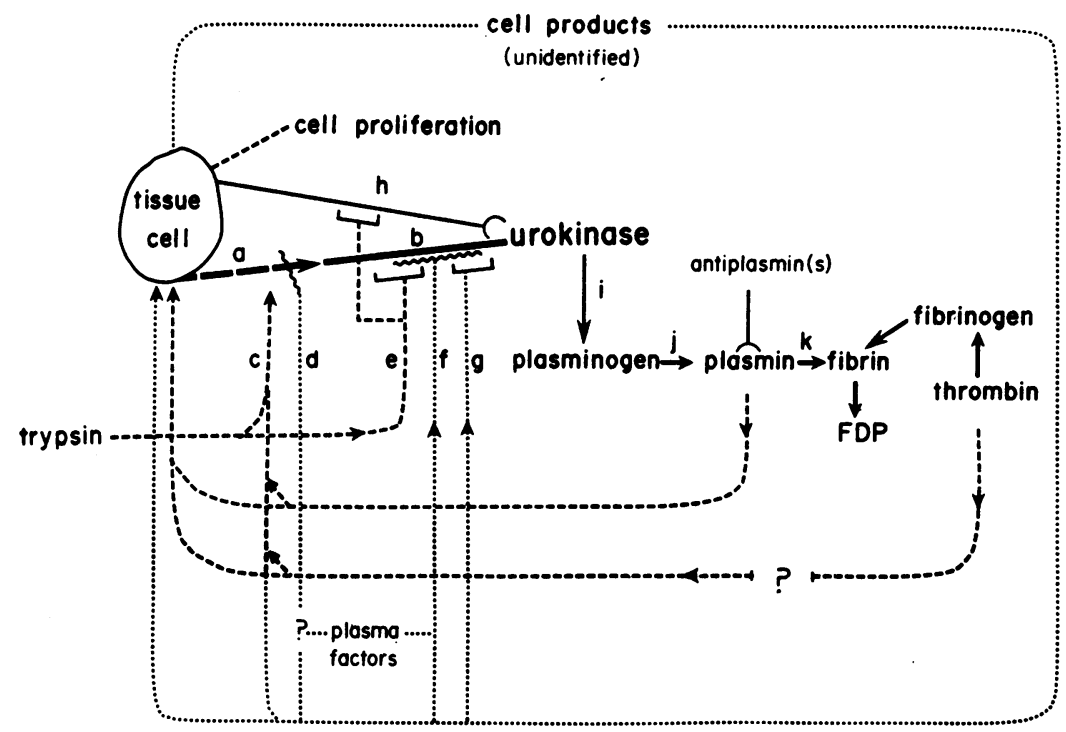

FIGURE 11 Present findings and concepts $(-\cdots, \cdots)$ in relation to previously known aspects of fibrinolysis (-) : $a=$ proenzyme (inactive urokinase precursor) $; b=$ urokinase; $\mathrm{c}=$ activation of proenzyme to urokinase; $\mathrm{d}=$ interferes with activation of proenzyme to urokinase; $\mathrm{e}=$ attacks urokinase or its inhibitor; $\mathrm{g}=$ attacks urokinase; $\mathrm{f}=$ prevents attack on urokinase; $h=$ inhibitor of urokinase; $i=$ activation of plasminogen to plasmin $(j)$ by urokinase; and $\mathrm{k}=$ lysis by-plasmin of fibrin formed through the action of thrombin on fibrinogen.

Modes of action by which plasmin and thrombin increase UK levels in culture appear to be manifold and may be directed towards the cells themselves as well as towards cell-produced material. The effect on cells is manifested by mitotic activity or, less frequently, cell injury and death. Although the effect of enzymes on cells influences UK levels, it does not account for the enhanced UK yields in culture. The increase in UK is explained best by the action of enzymes on material produced by cells and released into the supernates as shown by studies with cell-free systems. These studies involve four main areas-adsorption of UK to surfaces, UK inactivation or degradation, inhibition of UK by naturally occurring inhibitor(s), and formation of UK from inactive material.

In vitro loss of UK to surfaces and its recovery by gelatin has been described previously $(21,22)$ and is confirmed by the present observations. Plasmin and thrombin, however, do not influence UK adsorption to surfaces or the activity of UK itself. These enzymes also do not seem to affect UK inhibition by naturally occurring inhibitor(s) but act to prevent or delay UK degradation ("stabilizing" property) as well as to form UK from inactive material. "Stabilizing" property of thrombin, and to a lesser extent plasmin, appears to be similar to that observed with albumin and may be due, at least in part, to contamination with albumin elicited in the thrombins by immunoprecipitation techniques.
Such property contributes to UK levels in culture but is not responsible for the major mechanism of enhanced UK yields.

Urokinase has been shown to be produced in tissues throughout the body (2) although little is known about the production kinetics of this plasminogen activator. In the present study, inactive material giving rise to UK on exposure to proteolytic enzymes is found in such widely distributed organs as kidney, lung, spleen, and thyroid. Formation of UK from such material upon treatment with trace amounts of plasmin, thrombin, or trypsin suggests that: (a) UK is present in organs and tissues in an inactive form, i.e., as a proenzyme (UK precursor); $(b)$ inactive precursor can be activated to UK by a number of enzymes including those involved in clotting and fibrinolysis; and (c) such enzymatic activation represents the major mechanism leading to increased UK levels in cultured tissues.

Observations with trypsin indicate that UK levels also may be increased by release of UK from its inhibitor(s) as shown by the ability of trypsin, but not plasmin or thrombin, to induce recovery of UK from test tube mixtures of UK-inhibitor(s). Although the precise nature and kinetics of such release and relationship to UK formation from inactive material are yet to be defined, the present studies indicate that "release" and "formation" are distinct from each other, the former 
being achieved by the action of enzymes on UK inhibitor $(\mathrm{s})$ and the latter by activation of UK precursor.

Unlike numerous analogous systems in the field of enzymes, no proenzyme has been described for UK which appears to be excreted in urine in vivo (16) and released into supernates of cultured tissues in vitro $(1,2$, 4 ) in already activated form. The present observations suggest that activation of proenzyme occurs readily in such environments hampering investigation of UK in its inactive state. Although identity of activating enzymes in tissues or urine and factors favoring activation in these environments remain to be clarified, it may be speculated whether "spontaneous" activation in culture is accomplished by proteases such as certain cathepsins which are found in tissues and are known to act on trypsin-susceptible bonds of various substrates (23). Study with the present activating preparations suggests that UK precursor is a potential substrate for several proteases including trypsin, plasmin, and perhaps thrombin and thus conversion to UK may involve cleavage of peptide bonds susceptible to the action of these proteases (24-26).

Activation of UK precursor by proteases, particularly plasmin and thrombin, also should be examined in light of factors such as presence of impurities and possible cross-contamination of the enzymes used in the experiments. Plasmin is obtained by spontaneous activation of purified plasminogen (11) which is free of known contaminants such as prothrombin, thrombin, and thromboplastic material (11). A minor contaminating component observed in purified preparations of both plasmin and plasminogen (27) is thought to represent an "inert" form of plasmin (25). The ability of plasmin to induce $\mathrm{UK}$ at exceedingly low concentrations and at almost undetectable levels of its fibrinolytic function argues further against a contaminant and indicates that activation of UK precursor is part of the plasminogen-plasmin system and a property which is as important to fibrinolysis as the fibrinolytic activity of plasmin.

In contrast to plasmin, thrombin preparations may contain various contaminants $(28,29)$ including components of the plasminogen-plasmin system (29). Contamination with plasminogen and, presumably, traces of plasmin, appears to account for the activation of UK precursor by some of the present thrombin preparations, particularly the human thrombin. Activation observed with thrombin $\mathrm{B}$, however, is not readily explained through plasminogen-plasmin. Thrombin $\mathrm{B}$ preparation is free of plasminogen and although it exhibits some fibrinolytic activity, this can be considered a property of thrombin (30-33) distinct from that of plasmin (3133 ). It may be speculated whether the present in vitro activation of $\mathrm{UK}$ precursor by thrombin $\mathrm{B}$ is analogous to the ability of another thrombin preparation (31) to induce plasminogen activator activity in vivo (34-36). However, precise identity of activating properties of thrombin, relationship to similar function of plasmin, and the apparent ability of both proteases to induce $\mathrm{UK}$ in the absence of their respective primary activitiesclotting of fibrinogen, lysis of fibrin-await further investigation.

The apparent ability of plasmin and other enzymes, including unidentified enzyme $(\mathrm{s})$ in tissues, to induce $\mathrm{UK}$ from its precursor bears on aspects of orderly function of the fibrinolytic system as well as its disruption in pathological fibrinolytic states. Enzymes in tissues appear to be responsible for the continuous formation of UK in culture and, presumably, in vivo. Increased availability of UK from precursor which occurs through plasmin but may also be induced by thrombin and tissue enzymes provides mechanisms that accelerate the removal of fibrin deposits and clots. However, sudden massive activation of these mechanisms may disrupt the balance within the fibrinolytic system and lead to excessive fibrinolysis such as that seen in disseminated intravascular clotting (37-39) and various other pathological conditions (37). Inhibitors of fibrinolysis, i.e., antiurokinase $(3,5,6)$ and antiplasmins $(18,19)$, aid in preventing excessive fibrinolysis and factors interfering with or blocking formation of UK from precursor appear to provide additional safeguards. Such factors are detected in thrombin A but may reflect the presence of extraneous material in this preparation (29) rather than a property of thrombin itself. Preliminary studies of tissues in culture (now in progress) indicate that "blocking" property similar to that of thrombin A may be formed in tissues.

Cell proliferation observed after fibrin deposition contributes to the high UK yields but also leads to increase in UK inhibitor(s), thus maintaining equilibrium within the fibrinolytic system. Further, cell proliferation is relevant to events of tissue repair $(40,41)$ and proliferative disorders associated with fibrin deposition (42-44). The present observations suggest that mitosis-inducing factors may be mediated through plasmin, and perhaps also thrombin, and that cell proliferation is part of the intricate mechanisms which are set in motion locally in fibrin deposition and which involve the systems of clotting. fibrinolysis, and tissue repair.

\section{ACKNOWLEDGMENTS}

This work was supported by U. S. Public Health Service Grants AM 14018, AM 05614, and RR 48, and by a grant from the Otho S. A. Sprague Memorial Institute.

\section{REFERENCES}

1. Bernik, M. B., and H. C. Kwaan. 1967. Origin of fibrinolytic activity in cultures of the human kidney. I. Lab. Clin. Med. $70: 650$.

Increased Urokinase After Fibrin Deposition 833 
2. Bernik, M. B., and H. C. Kwaan. 1969. Plasminogen activator activity in cultures from human tissues. An immunological and histochemical study. J. Clin. Invest. 48: 1740 .

3. Bernik, M. B., and H. C. Kwaan. 1971. Inhibitors of fibrinolysis in human tissues in culture. Am. J. Physiol. 221: 916

4. Barlow, G. H., and L. Lazer. 1972. Characterization of the plasminogen activator isolated from human embryo kidney cells : comparison with urokinase. Thromb. Res. 1: 201.

5. Aoki, N., and K. N. von Kaulla. 1971. Human serum antiactivator: its distinction from antiplasmin. $\mathrm{Am}$. J. Physiol. 220: 1137.

6. Kawano, T., K. Morimoto, and Y. Uemura. 1970. Partial purification and properties of urokinase inhibitor from human placenta. J. Biochem. 67: 333 .

7. Pomerat, C. M. 1961. Cinematography: indispensable tool for cytology. Int. Rev. Cytol. 11: 307.

8. Bernik, M. B., and H. C. Kwaan. 1970. Stimulation of fibrinolytic activity in human cells in culture. Clin. Res. 18: 398. (Abstr.)

9. Committee on Terminology, Tissue Culture Association. 1967. Proposed usage of animal tissue culture terms. Cytogenetics (Basel). 6: 161.

10. Brakman, P. 1965. Bovine fibrinogen without detectable plasminogen. Anal. Biochem. 11: 149.

11. Sgouris, J. T., J. K. Inman, K. B. McCall, L. A. Hyndman, and H. D. Anderson. 1960. The preparation of human fibrinolysin (plasmin). Vox Sang. 5: 357.

12. Nilehn, J. E. 1967. Split products of fibrinogen after prolonged interaction with plasmin. Thromb. Diath. Haemorrh. 18: 89.

13. Silberman, S., M. B. Bernik, E. V. Potter, and H. C. Kwaan. 1973. Effects of Ancrod (Arvin) in mice. Studies of plasma fibrinogen and fibrinolytic activity. Br. J. Haematol. 24 : 101.

14. Lassen, M. 1952. Heat denaturation of plasminogen in the fibrin plate method. Acta Physiol. Scand. 27: 371.

15. Astrup, T., and S. Mullertz. 1952. The fibrin plate method for estimating fibrinolytic activity. Arch. Biochem. Biophys. $40: 346$.

16. White, W. F., G. H. Barlow, and M. M. Mozen. 1966. The isolation and characterization of plasminogen activators (Urokinase) from human urine. Biochemis'ry. $5: 2160$.

17. Fletcher, A. P, N. Alkjaersig, and S. Sherry. 1962. Fibrinolytic mechanisms and the development of thrombolytic therapy. Am. J. Med. 33: 738 .

18. Shulman, N. R. 1952. Studies on the inhibition of proteolytic enzymes by serum. II. Demonstration that separate proteolytic inhibitors exist in serum: their distinctive properties and the specificity of their action. J. Exp. Med. 95 : 593.

19. Norman, P. S. 1966. Antiplasmins. Fed. Proc. 25: 63

20. Alkjaersig, N., A. P. Fletcher, and S. Sherry. 1959. The mechanism of clot dissolution by plasmin. J. Clin. Invest. 38: 1086.

21. Lassen, M. 1958. The estimation of fibrinolytic components by means of the lysis time method. Scand. J. Clin. Lab. Invest. 10: 384

22. Kwaan, H. C., P. Brakman, and T. Astrup. 1967. Enhancement of fibrinolysis and thrombolysis by polysorbate 80 (Tween 80). Experentia. 23: 261.
23. Mycek, M. 1970. Cathepsins. Methods Enzymol. 19: 285

24. Keil, B. 1971. Trypsin. In The Enzymes. P. D. Boyer, editor. Academic Press, Inc., New York. 3: 249.

25. Robbins, K. C., and L. Summaria. 1970. Human plasminogen and plasmin. Methods Enzymol. 19: 184.

26. Magnuson, S. 1971. Thrombin and prothrombin. In The Enzymes. P. D. Boyer, editor. Academic Press, Inc., New York. $3: 277$.

27. Robbins, K. C., L. Summaria, D. Elwyn, and G. H. Barlow. 1965. Further studies on the purification and characterization of human plasminogen and plasmin. $J$. Biol. Chem. 240: 541 .

28. Cole, E. R., J. L. Koppel, and J. H. Olwin. 1964. Autoprothrombin $\mathrm{C}$ from a commercial thrombin product. Nature (Lond.). 202: 301.

29. Yin, E. T., and S. Wessler. 1968. Bovine thrombin and activated Factor X. J. Biol. Chem. 243: 112.

30. Lorand, L. 1954. Interaction of thrombin and fibrinogen. Physiol Rev. 34 : 742.

31. Landaburu, R. H., and W. H. Seegers. 1959. The acetylation of thrombin. Can. J. Biochem. Physiol. 37: 1361.

32. Triantaphyllopoulos, D. C., and C. R. Muirhead. 1968. Formation of anticoagulants by digesting fibrin with thrombin. Thromb. Diath. Haemorrh. 19: 397.

33. Muirhead, C. R., and D. C. Triantaphyllopoulos. 1971. Anticoagulants produced by thrombin from fibrin, the effect on blood coagulation, some physical characteristics. Thromb. Diath. Haemorrh. 26: 211.

34. Seegers, W. H., R. H. Landaburu, and J. F. Johnson. 1960. Thrombin-E as a fibrinolytic enzyme. Science (Wash. D. C.). 131: 726.

35. Landaburu, R. H., E. Giavedoni, and R. Santillan. 1968. Thrombin and acetylated thrombin in the activation of fibrinolysis. Can. J. Physiol. Pharmacol. 46: 809.

36. McCoy, L. E., H. A. Griscom, U. Diekamp, and W. H. Seegers. 1971. Experimental fibrinolysis with acetylated thrombin. Thromb. Diath. Haemorrh. Suppl. $47: 339$.

37. Rodriguez-Erdmann, F. 1965. Bleeding due to increased intravascular blood coagulation. Hemorrhagic syndromes caused by consumption of blood-clotting factors (consumption-coagulopathies). N. Eng. J. Med. 273: 1370.

38. McKay, D. G. 1969. Progress in disseminated intravascular coagulation. Calif. Med. 111: 186.

39. Hardaway, R. M., III. 1971. Disseminated intravascular coagulation. Thromb. Diath. Haemorrh. Suppl. 46: 209.

40. Astrup, T. 1968. Blood coagulation and fibrinolysis in tissue culture and tissue repair. Biochem. Pharmacol. Suppl. $17: 241$.

41. Chandler, A. B. 1970. Reversal and repair of vascular injury in thrombosis. Thromb. Diath. Haemorrh. Suppl. 40: 273 .

42. Vassali, P., and R. T. McCluskey. 1964. Pathogenic role of fibrin deposition in immunologically induced glomerulonephritis. Ann. N. Y. Acad. Sci. 116: 1052.

43. McCluskey, R. T., P. Vassali, G. Gallo, and D. Baldwin. 1967. Pathogenic role of the coagulation process in experimental and human glomerulonephritis. In Acute Glomerulonephritis. J. Metcoff, editor. Little, Brown and Company, Boston, Mass. 145.

44. Humair, L., E. V. Potter, and H. C. Kwaan. 1969. The role of fibrinogen in renal disease. I. Production of experimental lesions in mice. J. Lab. Clin, Med, 74: 60, 